\title{
Cena Ivana Franka 2017
}

\author{
Ivo Pospíšil (Brno)
}

Ve dnech 23.-25. 6. 2017 se ve Vídni v prostorách Institutu slavistiky Vídeňské univerzity konalo zasedání mezinárodní jury pro udělení Mezinárodní ceny Ivana Franka. Posuzována byla vědecká díla, která přispěla $\mathrm{k}$ rozvoji sociálních a humanitních věd a ukrajinistiky, a to díla lingvistická, literárněvědná, ekonomická, historická, politologická, religionistická, kulturologická aj. Mezinárodní jury byla složena ze zástupců různých zemí, za ČR zde byl autor této zprávy. Zasedání předcházelo poměrně složité posuzování jednotlivých prací recenzenty a členy jury, kteří navrhovali svá pořadí, která se poté na vídeňském zasedání konkretizovala. Autory jednotlivých děl byli většinou Ukrajinci, ale i ukrajinisté z jiných zemí. Mezi nominovanými díly byla kolektivní práce Jurije Makara, Mychajla Horného, Vitalije Makara a Anatolije Saljuka Od deportaci $k$ deportacím (1915-1947), Sofie Boňkovské o sakrální angioplastice Rusi-Ukrajiny, Oleha Šablije Sociálni geografie ve dvou dílech (za oblast sociálních a humanitních věd), za ukrajinistiku to byly práce Micha- ela Mosera New Contributions to the History of the Ukrainian Language, Zorjany Kupčynské Stratigrafie archaické ekonomie Ukrajiny a Volodymyra Serhijčuka Hladomor 1932-1933 jako genocida Ukrajinců. Dodal bych k tomu, že k nominantům došla jury na základě posuzování recenzenty a členy jury. Mezi kandidáty na nominaci byla také vynikající práce lvovského literárního vědce Jevhena Nahlika, který na pozvání Ústavu slavistiky přednášel i v Brně, Travestovaný svět Ivana Kotljarevského. Vyčerpávající vídeňské zasedání jury trvalo dva dny a došlo nakonec k jednoznačnému závěru. Ceny Ivana Franka byly předány 27. 8. 2017 v Drohobyči na Ukrajině v rámci ceremoniálu, jenž kromě toho zahrnoval i položení květin k památníku Ivana Franka v jeho rodišti Nahujeviči. Mezinárodní cenu Ivana Franka jako uznání vědeckých objevů na poli ukrajinistiky, sociálních a humanitních věd uděluje od roku 2016 Mezinárodní nadace Ivana Franka vždy 27. srpna v den Frankových narozenin. Cena je $\mathrm{v}$ dané oblasti pokládána za nejprestižnější mezinárodní ocenění.

prof. PhDr. Ivo Pospíšil, DrSc.

Ústav slavistiky

Filozofická fakulta, Masarykova univerzita

Arna Nováka 1, 60200 Brno, Česká republika

ivo.pospisil@phil.muni.cz 